\title{
Determinants of agricultural extension agents' internet competencies in Eastern Region of Ghana
}

\author{
Akpotosu, Bethel Worlah $\ \triangle$ \\ University of Cape Coast, Cape Coast, Ghana (bethelakpotosu@yahoo.com) \\ Annor-Frempong, Festus \\ University of Cape Coast, Cape Coast, Ghana (papaannor@yahoo.com) \\ Bosompem, Martin \\ University of Cape Coast, Cape Coast, Ghana (mbosompem@ucc.ed.gh)
}

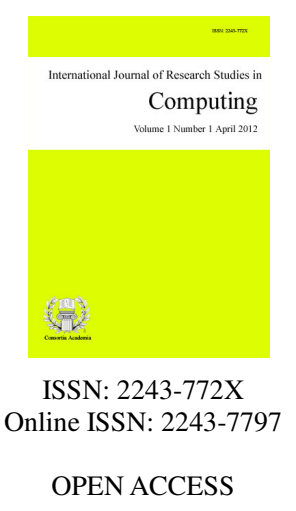

\begin{abstract}
Internet has been introduced by Ministry of Food and Agriculture to improve extension delivery in Ghana. However the extent to which extension agents have acquired the knowledge and skills to use it was not known in Eastern Region. The study looked at the determinants of Agricultural Extension Agents (AEAs) Internet competencies in the Eastern Region of Ghana. The study used descriptive survey design, stratified proportional sampling technique and validated questionnaire to collect data from 217 AEAs in ten districts of Eastern Region. Statistical tools such as frequencies, percentages, means, standard deviation, appropriate correlation coefficients were generated to describe or identify relationships among variables of the study. The study revealed that age, educational level, marital status, rank, location, years of experience, monthly salary, duration of use, years of using Internet, and training of AEAs relate significantly to Internet competencies of AEAs. The best predictors of Internet competencies of AEAs were training, location, duration of use, age and educational level.
\end{abstract}

Keywords: internet; extension delivery; competencies; training; location 


\section{Determinants of agricultural extension agents' internet competencies in Eastern Region of Ghana}

\section{Introduction}

Agriculture continues to be a major determinant of economic and social development in many developing countries. In Ghana, the agricultural sector employs more than $56 \%$ of the labor force and provides $30 \%$ of the gross domestic product as well as $41.1 \%$ of the foreign exchange earnings (Feed the Future, 2013). Agricultural extension, described as a non-formal educational system, plays a major role in the agricultural sector, and these include dissemination of agricultural information, building capacities of farmers and empowering the members of farm household (Sinkaye, 2005). Also, the extension system in Ghana helps farmers and other clientele to use scientific information, new technologies and improved practices on agricultural production and processing (Abankwa, 2004). Agricultural extension thrives on timely and relevant agricultural information, a critical resource required in the operation and management of agriculture enterprises (Asiedu-Darko, 2013).

Agricultural extension is still facing some constraints and challenges such as high cost of reaching farmers in the rural areas and loss of information associated with conventional extension. According to (Annor-Frempong, Kwarteng, Agunga, \& Zinnah 2006), these constraints can be addressed by using appropriate ICTs such as the Internet to provide cost effective information flow and facilitate practical information delivery and sharing of knowledge among Agricultural Extension Agents (AEAs) and other stakeholders in agricultural sector to help bridge the information gap. The Internet offers new opportunities for rapid communication and access to information worldwide. Internet is increasingly being used by all sectors of the society, to make resources more accessible to all people over the world. Also, the Internet provides a useful platform for agricultural extension agents to obtain better access to agricultural information and research by agricultural research scientists (Oladele, 2010; Ojedokun \& Owolabi, 2003; Oketunji, 2001). Further, the Internet is being used as a major source for agricultural information and knowledge dissemination to supplement information from Agricultural Information Centres (AIC) and library resources.

The Directorate of Agricultural Extension Service (DAES) of Ministry of Food and Agriculture (MoFA) in its effort to adhere to the internet drive, has launched the e-extension under the West Africa Agricultural Productivity Programme (WAAPP) to ensure qualitative extension delivery to farmers and other stakeholders. The e-extension involving the use of Internet and mobile telephones to disseminate information on proven technologies to farmers in remote areas of Ghana, is being promoted as an alternative extension delivery methodology (MoFA, 2013). The e-extension system is to offer opportunity to extension agents to use the Internet and mobile telephones to provide quality advisory services to farmers in every part of the country so as to improve agricultural productivity. The Ministry of Food and Agriculture has positioned herself to incorporate Internet into traditional extension methods due to the inadequate extension officers to educate many farmers in Ghana (MoFA, 2013).

\subsection{Statement of the Problem}

The agricultural extension service delivery in Eastern Region of Ghana continues to support agricultural development in Ghana through the linkages and support to agricultural research and technology transfer to farmers in rural communities. However, information flow among agricultural extension agents and farmers has not been adequate due to the inadequate extension staff to farmer ratio. Currently, Ghana has 2,600 agricultural extension staff working with the over 4 million farmers. This translates to a ratio of 1 extension agent to 1,700 farmers and as a result, falls short of the Food and Agricultural Organization standard of 1:1000 (Osei-Boateng, 2012). This challenging situation makes agricultural information dissemination ineffective; resulting in poor coverage. 
However, the effective application of Internet in agricultural extension depends on the Internet competencies of the AEAs to use it. The Government of Ghana and more specifically the Ministry of Food and Agriculture has identified the use of Internet as a tool that could improve extension delivery. Moreover, with proliferation of ICT and internet, many extension agents on their own have acquired knowledge and skills to apply in their work. In Ghana, little empirical data is available about AEAs' Internet competency level in extension delivery. More so, since MoFA launched the e-Agriculture and introduced Internet in some parts of Ghana, no study has assessed the AEAs' Internet competencies to establish whether and how Internet is applied to extension delivery. The proliferation and use of Internet in agricultural practices in Ghana leaves many questions unanswered and among these are salient questions such as; are agricultural extension agents adequately competent to use Internet? What are agricultural extension agents using the Internet for? What factors determine the Internet competencies of AEAs? The study therefore seeks to provide answers to these questions.

\subsection{Objective of the study}

The general objective of the study is to determine the variables that contribute to competencies of agricultural extension agents in the use of Internet in the Eastern Region of Ghana and the specific objectives are to:

$>$ Describe the demographic, work and Internet use backgrounds of agricultural extension agents.

$>\quad$ Frequency of Internet use by AEAs

$>$ Purpose of using the Internet

$>$ Examine the relationships between Internet competency level and demographics, work and Internet backgrounds of AEAs.

\section{Literature Review}

Studies on demographics of AEAs have shown that there is a close relationship between AEAs' demographic characteristics and the use of Internet (Agwu, Uche-Mba, \& Akinnagbe, 2008; Hefny, 2013). The main demographic characteristics that this study focused on are age, sex, educational level, household size, marital status, and income.

\subsection{Age of AEAs}

A good deal of literature shows that Internet competency is related to age. Age has inverse relationship with Internet use, implying older people have lower competency (Marquire, Jourdan-Boddaert, \& Huet, 2002). Hefny (2013) explained that age of individuals including extension agents affects their personal computer and Internet use because both computer and Internet require new learning skills and changing behavioral practices. Older individuals perceive technology as intimidating and perhaps mysterious and as a result, younger extension agents tend to use Internet more than their older colleagues.

\subsection{Sex of AEAs}

Studies that examined gender issues on Internet usage show results that are not consistent. For example, Schumacher and Morahan-Martin (2001) reported that males have greater Internet skills than females do. Goulding and Spacey (2002), also assert that males have more knowledge about the Internet and how to use it than females since the latter have been slower to start using the Internet than their counterparts male. Moreover, males tend to use the Internet more frequently and for longer periods than females (Ono \& Zavodny, 2003; Wasserman \& Richmond-Abbott, 2005). Agwu et al., (2008) noted in their study on extension workers in Nigeria that majority of extension workers were males which is due to the gender difference found in public services in Nigeria. 
On the other hand, in studying differences in gender, Bimber (2000) controlled socio-economic and demographic characteristics, and although female were less likely than male to use the Internet frequently, he concluded that this was the product of socio-economic and other factors, not gender itself. Also, findings by Ono and Zavodny (2003) showed slight variation by gender in access to the Internet in the developed Western countries. Similarly, Hargittai, and Shafer (2006) establish that males and females do not vary significantly in their online competences, but that women's self-assessed skill is significantly lower than that of male.

\subsection{Educational Level of AEAs}

The use of Internet in obtaining information requires intellectual ability, and therefore education plays a major role in determining ones Internet competency. There is a limited amount of research that looked at the relationship between educational level and Internet use. In most of the studies, educational level is not included or considered as a main construct but measured as part of demographic characteristics (Teo, 2001). Another study by Awgu et al. (2008) showed that educational level has a significant positive influence on perceived usefulness of Internet and computers. All together, these findings imply that higher educational level is likely to have positive relationship with usage. Additionally, higher educational level may result in better knowledge about Internet use and computers; thus, facilitating Internet usage. Zhang (2004) concluded that, the more educated people are, the more useful they felt Internet to be.

\subsection{Household size of AEAs}

Household size may be referred to as the number of people who depend on AEA for their livelihood. Literature indicates that many consultations take place among family members on adoption or the use of new technology or household activity. According to Feder, Just, and Zilberman (1985), the household members available may affect their ability and willingness to adopt and use a new technology. Knepper (2002) also observed larger households tend to have more negative implications on new technology adoption and use than smaller ones.

\subsection{Income of $A E A s$}

Regarding income, differences in computer ownership and Internet access are narrowing, however, differences can be seen in the way they are used (Hargittai, 2008). People with a higher income are more likely to seek news and product information, make online travel arrangements, and perform work-related activities online than those with lower income (van Deursen, 2010). Internet use is directly related to person's income level. Mukoko (2012) concluded that income is one of the main drivers of Internet adoption and use in Cameroon.

\subsection{Work Experience}

Research has found that most studies used time on the job or tenure to measure work experience. This is further supported by some researchers suggesting that experience leads to job relevant knowledge gained over time (Fiedler, 2007; McCall, 2004). Judge, Jackson, Shaw, Scott, and Rich (2007) found the relationship between work experience and job performance to be influenced by two variables: length of experience and job complexity. Work experience is therefore tends to have an influence on performance and behavior.

\subsection{Location of AEAs}

According to Al-Hammadany and Heshmati (2011) the location of the Internet user played a significant role on Internet use in developing countries. Living in the provinces of southern Iraq (that is the rural areas) shows a negative impact on the use Internet compared with the cities and urban areas. Hence, one could expect a positive relationship between urbanization and Internet access and use. In general, cities are better networked than rural areas (Wunnava \& Leiter, 2009). This is mostly due to practical and economic reasons. Studies such as 
Xiaoming and Kay (2004) and Crenshaw and Robison (2006) have found urban population to have a significant impact on Internet diffusion.

\section{Methodology}

\subsection{Research Design}

The study design was a descriptive survey and this design was deemed appropriate because survey usually examines a sample for the purpose of making conclusion about the population from which the sample was drawn (Vanderstoep \& Johnston, 2009). Surveys are very robust and used to collect large amount of data from many diverse people in a short amount of time. Muijs (2004) had argued that survey research is appropriate for descriptive studies where researchers are interested in examining relationships between variables occurring in particular real-life contexts. For instance, the extent relationship between two or more variables using correlation coefficient and to make predictions. Hence, the design was deemed appropriate (Stanovich, 2007).

\subsection{Data collection Procedure}

The study population comprises all agricultural extension agents in the Eastern Region of Ghana. They number five hundred and fifteen (515) according to the staff lists collated from the regional office of MoFA at Koforidua. To ensure that the sample size is representative, the table of determining sample size (Krejcie \& Morgan, 1970) was used. According to this table, for population of 500 which is very close to study population of 515, a sample size of 217 would be required to be representative. The next stage was selection of sample size from each districts and municipality since location was a factor in receiving Internet competency. A stratified proportion sampling procedure was adopted at this stage. The stratified proportional random sampling technique was used to obtain the sample size. The region was stratified into two (2) strata namely municipal and district. Proportional sampling was applied at this stage to obtain the number of respondents in municipals and districts, and then the municipals and districts were selected randomly. After getting the sample municipalities and districts, all AEAs in the sampled municipals and districts were used in the study. Questionnaire was used as the instrument for data collection and this was used because the population was literate.

\subsection{Data analysis}

Data collected from the field were organized, edited, coded and entered for analysis using the Statistical Package for Social Sciences (SPSS) version 21.0 software. To describe the demographic characteristics of agricultural extension agents in Eastern Region, frequencies, percentages, mean and standard deviations were computed to describe variables such as age, sex, educational level, income level and years of experience, location and marital status of extension agents. A combination of correlational coefficients (Pearson, Point Biserial, Biserial, and Spearman) were used to determine the relationships between Internet competency levels and demographics, work and Internet backgrounds of AEAs.

A linear multiple regression was used to predict Internet competencies of AEAs from the demographic, work and Internet backgrounds of AEAs. The regression model is given as;

$$
Y=a+\beta_{1} X_{1}+\beta_{2} X_{2}+\beta_{3} X_{3}+\beta_{4} X_{4}+\beta_{5} X_{5 \ldots}+\beta_{11} X_{11}+E . \text { Where }
$$

$Y=$ Internet competency level; $a=$ constant; $\beta_{l}-\beta_{n=}$ beta coefficients of predictor variables;

$X_{1}=$ Rank of AEAs; $X_{2}=$ Marital status of AEAs; $X_{3}=$ Sex of AEAs; $X_{4}=$ Location of AEAs; $X_{5}=$ Years of experience of AEAs; $X_{6}=$ Age of AEAs; $X_{7}=$ Level of education; $X_{8}=$ Monthly salary of AEAs; $X_{9}=$ Duration of Use of Internet; $X_{10}=$ Training received on Internet; $X_{11}=$ Years of Internet use. 
Akpotosu, B. W., Annor-Frempong, F., \& Bosompem, M.

\section{Table 1}

The Codes, Sign and Explanatory variables used in the Regression Analysis

\begin{tabular}{|c|c|c|c|}
\hline $\begin{array}{l}\text { Explanatory } \\
\text { variables }\end{array}$ & Codes & Sign & Explanation (Assumption) \\
\hline Age & Number of years & + & $\begin{array}{l}\text { Young age increases the probability of obtaining high } \\
\text { Internet competency }\end{array}$ \\
\hline Sex & $\begin{array}{l}1=\text { Male } \\
0=\text { Female }\end{array}$ & + & $\begin{array}{l}\text { Probability that males have higher Internet competency } \\
\text { than females }\end{array}$ \\
\hline Education level & Educational level & + & $\begin{array}{l}\text { Higher education increases the probability of high } \\
\text { Internet competency acquisition }\end{array}$ \\
\hline Monthly salary & Monthly salary & + & $\begin{array}{l}\text { Higher salary increases the probability of high Internet } \\
\text { competency acquisition }\end{array}$ \\
\hline $\begin{array}{l}\text { Duration of use of } \\
\text { Internet }\end{array}$ & Number of hours & + & $\begin{array}{l}\text { Long hours spent on Internet increases the probability of } \\
\text { high Internet competency acquisition }\end{array}$ \\
\hline Class & $\begin{array}{l}1=\text { Professional } \\
0=\text { Technical }\end{array}$ & + & $\begin{array}{l}\text { Higher class increases the probability of high Internet } \\
\text { competency }\end{array}$ \\
\hline $\begin{array}{l}\text { Years of } \\
\text { experience }\end{array}$ & No of Years at MoFA & - & $\begin{array}{l}\text { Long years in MoFA decreases the probability of } \\
\text { Internet competency }\end{array}$ \\
\hline Marital status & $\begin{array}{l}1=\text { Not married } \\
0=\text { Married }\end{array}$ & Positive & $\begin{array}{l}\text { Probability that, not married have higher Internet } \\
\text { competency than married respondents }\end{array}$ \\
\hline Location & $\begin{array}{l}1=\text { Rural } \\
0=\text { Urban }\end{array}$ & Negative & Rural decreases the probability of use of Internet \\
\hline Training received & $\begin{array}{l}1=\text { Training on Internet } \\
0=\text { No Training }\end{array}$ & + & $\begin{array}{l}\text { Training increases the probability of higher Internet } \\
\text { competency acquisition }\end{array}$ \\
\hline $\begin{array}{l}\text { Years of Internet } \\
\text { use }\end{array}$ & Number of years & + & $\begin{array}{l}\text { Higher number of years of Internet use increases the } \\
\text { probability of acquiring high Internet competency }\end{array}$ \\
\hline
\end{tabular}

\section{Results and Discussions}

This chapter presents and discusses the results in line with the objectives of the study. The chapter starts with the discussion on findings on the demographic characteristics of AEAs. Furthermore, the extent of Internet use by AEAs in extension delivery, the level of Internet competencies (knowledge, attitude and skill) of AEAs, and the factors that predict the Internet competencies of AEAs are presented and discussed.

\section{Demographic characteristics of Agricultural Extension Agents}

\subsection{Age of Agricultural Extension Agents}

The data in Table 1 shows that close to one-fifth (19.8\%) of respondents are very youthful (aged up to 30 years) while more than half $(53.9 \%)$ of the AEAs were between 31 and 50 years. The mean age of the respondents of 41.7 years and a standard deviation of 10.8 years indicate that although the ages of respondents highly varied, they are found within the active age bracket of up to 53 years. Age has significant implication for Internet usage. Agwu et al. (2008) and Agwu and Chan (2007) found elderly extension workers, researchers and farmers in Nigeria to be interested in using high technology. With majority of the respondents in their active age, the contrary is expected with AEAs in Eastern Region of Ghana.

\subsection{Sex of Agricultural Extension Agents}

Table 1 further revealed that 85.3 percent of the respondents were males whilst 14.7 percent were females. This shows that majority of the AEAs were males reflecting high gender difference in staff ratio found in the 
Ministry of Food and Agriculture in Ghana. The national ratio is about 5 males to 1 female (Ministry of Food and Agriculture, 2010). This finding also conforms to Agwu et al. (2008) whose study on extension workers, researchers and farmers in Nigeria reveal that majority of them were males. The results also revealed that more than a quarter, 26.3 percent, would be retiring in the next 10 years which implies employing new staff who may be more interested in using Internet in extension delivery in the Eastern Region of Ghana.

\subsection{Educational Level of AEAs}

The results show that majority of the respondents $(71.0 \%)$ have certificate and diploma degrees in agriculture while only a few of the participants had higher degrees (Master degree $-9.2 \%$ and $0.5 \% \mathrm{PhD}$ degree) as revealed in Table 1. This could be due to the notion that most AEAs were employed with certificate degree. This conforms to Agwu et al. (2008) that majority of extension workers in Abia and Enugu States of Nigeria had HND certificates while 32.5\% had BSc. In contrast, the study by Ahmadpour and Soltani (2012) revealed that about $78 \%$ of agricultural extension workers in Iran were BSc and higher degree holders with greater appreciation of the importance of Internet. This implies that all the respondents are literates and should be able to appreciate the use of Internet in their extension duties. In Arokoyo (2005)'s study on ICTs application in Agricultural Extension service delivery in Nigeria, high level of illiteracy was identified as a serious constraint to ICT utilization by extension workers and farmers in Nigeria.

\subsection{Years of Experience of AEAs}

Similarly results in Table 1 shows that most (66.3\%) of the AEAs had work experience ranging from 1-20 years. The mean years of work experience of 15.1 years with standard deviation of 10.6 years show that AEAs have relatively varied experiences in extension. The results are consistent with the findings of Adesope, Asiabaka, and Agumagu (2007) in their studies with characteristics of extension managers and supervisors on information technology needs in the Niger Delta area of Nigeria, which found out that majority of the respondents had work experience ranging from 5 to 15 years with mean work experience of 15.52 years. This is further supported by some researchers suggesting that experience is the job-relevant knowledge gained over time, (Champoux, 2011; Driskill \& Brenton, 2005). Since individuals are products molded by every experience in life, our past and present experiences continuously affect the development and shape of knowledge, skills, attitudes, beliefs and behaviors (Steers, 2011). McDaniel, Anderson, and Wildman (2007) found out the relationship between work experience and job performance to be influenced by two variables: length of experience and job complexity.

\subsection{Marital Status of AEAs}

In the same way, Table 1 illustrates that most of the AEAs (69.6\%) were married, while $0.9 \%$ are widowed. This is similar to findings of Mabe and Oladele (2012) who reported that $70.1 \%$ of extension officers in the North-West province of South Africa were married. Also, Taylor et al. (2012) assessed the use of Internet in extension delivery and agriculture in Australia and concluded that a difference in attitude towards Internet use and agriculture among single extension workers and extension workers who are married and have children.

\subsection{Location}

Results further reveal that (69.1\%) live in their area of operation. Mabe and Oladele (2012) reported similar findings in their studies in North-West Province, South Africa that majority of extension workers reside in their areas of operation. Zwane (2009) also reported similar findings in Lipopo province of South Africa that extension officers live in their job locations. An individual who uses the Internet in urban areas typically has the opportunity to use the Internet frequently and for longer periods than respondents of rural areas. This is because Internet connectivity is better in urban areas than rural areas (McDonald \& Siegall, 2008). (Table 2) 
Akpotosu, B. W., Annor-Frempong, F., \& Bosompem, M.

\subsection{Income of Respondents}

The results depicts in Table 1 show that majority of the respondents (86.1\%) receive between GHS 500 and GHS 1,500 per month. The mean salary is GHS 1,156.30, while 14.9 percent of the respondents received salary between GHS 2,001 and 2,500. These figures imply the salary levels of AEAs are very low, and most respondents may not be able to afford personal computer, use Internet and consequently a negative effect on Internet competency. Consistent with a study by Jaaskelainen and Savolaine (2003) in Finland, people with the highest level of network competency had relatively high level of income.

Table 2

Demographic, Work and Internet Use Background of Agricultural Extension Agents

\begin{tabular}{|c|c|c|c|c|c|}
\hline Variables & Categories & Frequency & $\%$ & Mean & $\mathrm{SD}$ \\
\hline \multirow[t]{4}{*}{ Age } & $21-30$ & 43 & 19.8 & 41.73 & 10.78 \\
\hline & $31-40$ & 57 & 26.3 & & \\
\hline & $41-50$ & 60 & 27.6 & & \\
\hline & $51-60$ & 57 & 26.3 & & \\
\hline \multirow[t]{2}{*}{ Sex } & Male & 185 & 85.3 & & \\
\hline & Female & 32 & 14.7 & & \\
\hline \multirow[t]{5}{*}{ Education } & Certificate & 92 & 42.4 & & \\
\hline & Diploma & 62 & 28.6 & & \\
\hline & Bachelor Degree & 42 & 19.4 & & \\
\hline & Master's Degree & 20 & 9.2 & & \\
\hline & $\mathrm{PhD}$ & 1 & 5 & & \\
\hline \multirow[t]{4}{*}{ Experience (Years) } & $1-10$ & 81 & 37.5 & 15.10 & 10.57 \\
\hline & $11-20$ & 63 & 29.0 & & \\
\hline & $21-30$ & 58 & 26.7 & & \\
\hline & $31-41$ & 15 & 6.9 & & \\
\hline \multirow[t]{4}{*}{ Marital Status } & Married & 151 & 69.6 & & \\
\hline & Single & 54 & 24.9 & & \\
\hline & Divorced & 10 & 4.6 & & \\
\hline & Widow & 2 & 0.9 & & \\
\hline \multirow[t]{2}{*}{ Location } & Rural & 150 & 69.1 & & \\
\hline & Urban & 67 & 30.9 & & \\
\hline \multirow[t]{4}{*}{ Income } & 500-1,000 & 78 & 35.9 & & \\
\hline & $1,001-1,500$ & 109 & 50.2 & & \\
\hline & $1,501-2,000$ & 19 & 8.8 & & \\
\hline & $2,001-2,500$ & 11 & 5.1 & & \\
\hline
\end{tabular}

\subsection{Frequency of Internet Usage}

Findings presented in Table 2 reveal that majority of AEAs (85.3\%) never use Internet from computers or laptops at office. Equally $68.2 \%$ of the AEAs also have never used the Internet from home. The results further indicated that AEAs often (mean=3.24, $\mathrm{SD}=1.26$ ) use Internet from their mobile telephones while $55.3 \%$ of the AEAs also have never used the Internet café/Business centres to access. The results indicated that AEAs do not use the Internet frequently for their work as they are affected by social amenities available in their various locations. This finding is different from earlier studies by Ogunjobi and Fagbami (2012) who established that in Nigeria more than half agricultural extension agents in Ibadan, Oyo State used Internet every day of the week for their work. 
Table 3

Frequency of Use of Internet

\begin{tabular}{|c|c|c|c|c|c|c|c|c|c|c|}
\hline \multirow[t]{2}{*}{ Source } & \multicolumn{2}{|c|}{$\begin{array}{l}\text { Never } \\
(0)\end{array}$} & \multicolumn{2}{|c|}{$\begin{array}{l}\text { Sometimes } \\
\text { (once a week) }\end{array}$} & \multicolumn{2}{|c|}{$\begin{array}{c}\text { Often } \\
\text { (thrice a } \\
\text { week) }\end{array}$} & \multicolumn{2}{|c|}{$\begin{array}{c}\text { Always } \\
\text { (every day of } \\
\text { the week) }\end{array}$} & \multirow[t]{2}{*}{ Mean } & \multirow[t]{2}{*}{ SD } \\
\hline & Freq & $\%$ & Freq & $\%$ & Freq & $\%$ & Freq & $\%$ & & \\
\hline Mobile Phone internet & 94 & 43.3 & 33 & 15.2 & 33 & 15.2 & 57 & 26.3 & 3.24 & 1.26 \\
\hline $\begin{array}{l}\text { Computer/ Laptop at } \\
\text { Home }\end{array}$ & 148 & 68.2 & 21 & 9.7 & 22 & 10.1 & 26 & 12 & 1.66 & 1.07 \\
\hline $\begin{array}{l}\text { Internet café/Business } \\
\text { centre }\end{array}$ & 120 & 55.3 & 80 & 36.9 & 11 & 5.1 & 6 & 2.8 & 1.55 & 0.72 \\
\hline $\begin{array}{l}\text { Computer/ Laptop at } \\
\text { office }\end{array}$ & 185 & 85.3 & 19 & 8.8 & 6 & 2.6 & 7 & 3.2 & 1.24 & 0.66 \\
\hline
\end{tabular}

Note. $\mathrm{n}=217$. Source. Field Survey Data, $2014 *$ Multiple response. Means were calculated from a scale of $1=$ Never, $2=$ Somehow (once a week), $3=$ Often (thrice a week), 4= Always (every day of the week).

\subsection{The Purpose of Using Internet}

The results presented in Table 3 show that AEAs mainly use Internet to send (82.8\%) and receive (83.4\%) emails. Furthermore, the Internet is used to access payslips from the Controller and Accountant General Department (77.9\%), search for information on agriculture (71.8\%), network on social media such as Facebook, Twitter and Whatsapp (64.4\%). About two thirds (59.5\%) indicated that they use Internet to read news on agriculture. The results further reveal that only few AEAs used the Internet for the purpose of extension delivery, to communicate with farmers (16\%); to communicate with researchers (24.5\%) and listen to online news on agricultural program (21.5\%). An earlier study conducted by Ruzgar (2005) on the purpose for the Internet use and learning through Internet in Istanbul revealed that internet usage in search of information on agriculture was approaching $100 \%$. It also revealed that sending and receiving emails topped the list, followed by reading news and chatting.

\section{Table 4}

The Purpose of Using Internet

\begin{tabular}{lcc}
\hline \multicolumn{1}{c}{ Purpose } & Freq. & Percent \\
\hline Receiving e-mail & 136 & 83.4 \\
Sending e-mail & 134 & 82.2 \\
Accessing payslip (e-payslip) & 127 & 77.9 \\
Searching for information on agriculture & 117 & 71.8 \\
Social networking (using Facebook, Whatsapp, Twitter) with AEAs/ farmers & 105 & 64.4 \\
Reading news on agriculture & 97 & 59.5 \\
Chatting with colleagues & 91 & 55.8 \\
Accessing MoFA's Website & 87 & 53.4 \\
Downloading media (audio and video) files on agriculture & 65 & 39.9 \\
Subscribing/ reading newspaper on agriculture & 54 & 33.1 \\
Communicating with other workers using Skype, Viber & 53 & 32.5 \\
Communicating with researchers & 40 & 24.5 \\
Listening to online radio on agricultural programme & 35 & 21.5 \\
Communicating with farmers & 26 & 16 \\
Doing online shopping (agrobased pdfs) & 10 & 6.1 \\
\hline
\end{tabular}

Note. $\mathrm{n}=163$. Source. Field Survey Data, 2014. 
Akpotosu, B. W., Annor-Frempong, F., \& Bosompem, M.

4.10The Relationships between Internet Competency and Backgrounds (Demographic, Work and Internet) of

\section{Agricultural Extension Agents}

A correlation table showing the relationship between Internet competency and demographic, work and Internet backgrounds of AEAs is presented in Table 4. To establish the relationship between Internet competency and background characteristics (demographic, work and Internet), variables were estimated as follows: the overall Internet competency was estimated as composite mean (Y) from knowledge, attitude and skill.

$Y=$ Internet competency

$X_{1}=$ Rank (1= Technical officer, $2=$ Production officer, $3=$ Agriculture officer .

$X_{2}=$ Marital status $(1=$ Not married, $0=$ Married $)$

$X_{3}=\operatorname{Sex}(1=$ Male, $0=$ Female $)$

$X_{4}=$ Location $(1=$ Rural, $0=$ Urban $)$

$X_{5}=$ Years of working Experience (Years)

$X_{6}=$ Age $($ Years $)$

$X_{7}=$ Educational Level (1= Certificate, 2= Diploma, 3= Bachelor degree, $4=$ Master's degree, 5= $\left.\mathrm{PhD}\right)$.

$X_{8}=$ Monthly Salary (Ghana cedis)

$X_{9}=$ Duration of Use (Hours)

$X_{10}=$ Training $(1=$ Training, $0=$ No training $)$

$X_{11}=$ Years of using Internet (Years)

There were significant relationships between Internet competency and ten (10) of the background variables (independent) except in the case $\operatorname{sex}(\mathrm{r}=.040 ; p<.562)$ at 0.05 alpha level. The finding mirrors that of Anandarajan, Simmers, and Igbaria (2000) who found that sex has no relationship with Internet competency and Internet usage of US employees at their workplace. This implies that sex had no effect on whether an AEA use Internet or not.

There were positive and substantial significant (Davis, 1971) relationships between AEA's Internet competency and educational level $(\mathrm{r}=.665 ; p<.001)$, years of using Internet $(\mathrm{r}=.652 ; p<.000)$, training $(\mathrm{r}=.580$; $p<.001)$ and rank $(\mathrm{r}=.523 ; p<.001)$. These positive relationships imply that educational level, years of using Internet, training and rank contribute to increases in Internet competency attained by AEAs. Education plays a significant role in creating awareness and interest in innovations and also fundamental to understanding the usage and functionalities of the Internet (Eden \& Ofre, 2010). This implies that the kind of education and training AEAs have about the Internet influences the competency. For example, the more trainings and higher education AEAs have, the higher their competency.

There was a positive and moderate significant relationship (Davis, 1971) between AEA's Internet competency and duration of Internet use $(\mathrm{r}=.463 ; p<.001)$. This implies that the duration of hours one uses the Internet affects the competency; the longer one uses the Internet the higher the competency (Okay, 2010). There were negative and moderate significant relationship (Davis, 1971) between AEA's Internet competency and age $(\mathrm{r}=-.486 ; p<.001)$, years of working experience $(\mathrm{r}=-.486 ; p .001)$, monthly salary $(\mathrm{r}=-.315 ; p<.001)$ and location $(\mathrm{r}=-.312 ; p<.001)$. These findings support Rohde and Shapiro (2000) assertion that level of Internet competency falls with age and years of experience. The younger extension workers use Internet more than veteran extension workers and for that matter have higher Internet competency than the aged extension agents.

The negative correlation found between monthly salary (income) and Internet competencies are not surprising as the aged were more experienced and obtain high income; hence, the inverse relationships. This 
finding is inconsistent with Rohde and Shapiro's (2000) finding that income has positive relationship with Internet competency level. The explanation for this finding is that income or monthly salary of staff of MoFA increases with years of experience. The negative substantial relationship (Davis, 1971) found between AEAs' age and their Internet competency $(\mathrm{r}=-.486 ; p<.001)$ implies that younger respondents tend to have higher Internet competency than older respondents.

Table 5

Distribution of Relationship between Internet Competency and Demographic Background (Work and Internet) of Agricultural Extension Agents

\begin{tabular}{lccll}
\hline \multicolumn{1}{c}{ Independent variables } & $\begin{array}{c}\text { Correlation } \\
\text { Coefficient }(\mathrm{r})\end{array}$ & $\begin{array}{c}\text { Significance } \\
(\mathrm{p})\end{array}$ & $\begin{array}{c}\text { Type of } \\
\text { correlation }\end{array}$ & $\begin{array}{c}\text { Strength of } \\
\text { relationship }\end{array}$ \\
\hline Rank $X_{1}$ & $0.523^{* *}$ & 0.001 & Biserial & Substantial \\
Marital status $X_{2}$ & $0.246^{* *}$ & 0.001 & Biserial & Low \\
Sex $X_{3}$ & 0.040 & 0.562 & Point Biserial & - \\
Location $X_{4}$ & $-0.312^{* *}$ & 0.001 & Biserial & Moderate \\
Years of Experience $X_{5}$ & $-0.486^{* *}$ & 0.001 & Pearson & Moderate \\
Age $X_{6}$ & $-0.486^{* *}$ & 0.001 & Pearson & Moderate \\
Education level $X_{7}$ & $0.665^{* *}$ & 0.001 & Spearman & Substantial \\
Monthly salary $X_{8}$ & $-0.315^{* *}$ & 0.001 & Pearson & Moderate \\
Duration of use $X_{9}$ & $0.463^{* *}$ & 0.000 & Pearson & Moderate \\
Training $X_{10}$ & $0.580^{* *}$ & 0.001 & Biserial & Substantial \\
Years of using Internet $X_{11}$ & $0.652^{* *}$ & 0.000 & Pearson & Substantial \\
\hline
\end{tabular}

Source. Field Survey Data, 2014. *** $p<0.01 * p<0.05$

Results in Table 4 also indicate a low and positive significant relationship ( $\mathrm{r}=.246 ; p<.001)$ between AEA's Internet competency and marital status. In other words, married AEAs were more competent in usage of Internet than unmarried AEAs.

\subsection{Collinearity Diagnostic Test from Demographics, Work and Internet background of Agricultural Extension}

Agents

Variance Inflation Factor (VIF) measures the amount by which the variance of a parameter estimator is inflated due to predictor variables being correlated with each other (Dupuis \& Victoria-Feser, 2013; O'Brien, 2007). VIF close to 10 is a cause for worry, while tolerance of 1 indicates no collinearity while tolerance value of zero (0) indicates a severe collinearity problem (Bosompem, Annor-Frempong, \& Achiaa, 2013; Cohen et al., 2003). The result of the collenearity test presented in Table 5 shows no collenearity issues, therefore, the ten (10) independent variables were used for the prediction.

Results in Table 6 show that years of Internet use $\left(X_{11}\right)$, training $\left(X_{10}\right)$, location $\left(X_{4}\right)$, duration of use $\left(X_{9}\right)$, age $\left(X_{6}\right)$, and educational level $\left(X_{7}\right)$ were the best predictors of Internet competency level of AEAs in the study. The adjusted R-squared of 0.563 suggests that the six predictor variables explain about $56.3 \%$ of the variance/variation in Internet competency. Individually, years of Internet use is contributing $39.4 \%$ to the variation, while training contributes $(7.8 \%)$, location $(3.7 \%)$, duration of use $(2.6 \%)$, age $(1.6 \%)$, and educational level $(1.2 \%)$.

The contribution of years of Internet use, although, mirrors work done by Scheer (2011) on extension educators in U.S.A, the $39.4 \%$ of the variance or variation in Internet competency ascribed to how long educators in U.S.A had used Internet. Contrary, Yakubu (2011) had reported that training of extension workers in north-west zone of Nigeria in the use of Internet contributed $25 \%$ of variation in extension worker's competency level. In this case, education contributed only $1.2 \%$ in the variation. Educational level of AEAs is generally low 
Akpotosu, B. W., Annor-Frempong, F., \& Bosompem, M.

compared to those in Singapore.

\section{Table 6}

Collinearity Diagnostic Test from Demographics, Work and Internet background of Agricultural Extension Agents

\begin{tabular}{lccc}
\hline \multicolumn{1}{c}{ Independent Variable } & Variance Inflation & Tolerance & p-value \\
\hline Years of Internet use $\left(X_{11}\right)$ & Factor & 0.538 & 0.000 \\
Training $\left(X_{10}\right)$ & 1.860 & 0.874 & 0.000 \\
Duration of use $\left(X_{9}\right)$ & 1.144 & 0.910 & 0.005 \\
Location $\left(X_{4}\right)$ & 1.099 & 0.757 & 0.006 \\
Age $\left(X_{6}\right)$ & 1.322 & 0.767 & 0.002 \\
Level of education $\left(X_{7}\right)$ & 1.305 & 0.598 & 0.022 \\
Rank $\left(X_{1}\right)$ & 1.672 & 0.777 & 0.020 \\
Sex $\left(X_{3}\right)$ & 1.288 & 1.000 & 0.979 \\
Marital status $\left(X_{2}\right)$ & 1.000 & 0.965 & 0.028 \\
Years of working experience $\left(X_{5}\right)$ & 1.036 & 0.839 & 0.044 \\
Monthly salary $\left(X_{8}\right)$ & 1.191 & 0.996 & 0.153 \\
\hline
\end{tabular}

Note. $\mathrm{n}=217 * p<0.05$. Source. Field Survey Data, 2014

Table 7

Stepwise Regression of Internet Competency of AEAs

\begin{tabular}{llccccccc}
\hline \multicolumn{1}{c}{ Predictors } & $\begin{array}{c}\text { Step of } \\
\text { Entry }\end{array}$ & $\begin{array}{c}\text { Beta } \\
\text { (standardized) }\end{array}$ & $\mathrm{R}^{2}$ & Adj R $^{2}$ & $\begin{array}{c}\text { Adj R } \\
\text { Change }\end{array}$ & S.E.E & F. Reg. & F. Sig* \\
\hline$X_{11}$ & 1 & 0.344 & 0.398 & 0.394 & 0.394 & 0.705 & 106.465 & 0.000 \\
$X_{10}$ & 2 & 0.208 & 0.479 & 0.472 & 0.078 & 0.658 & 73.512 & 0.000 \\
$X_{4}$ & 3 & -0.157 & 0.518 & 0.509 & 0.037 & 0.635 & 57.029 & 0.000 \\
$X_{9}$ & 4 & 0.166 & 0.547 & 0.535 & 0.036 & 0.618 & 47.614 & 0.002 \\
$X_{6}$ & 5 & -0.184 & 0.564 & 0.551 & 0.016 & 0.607 & 40.691 & 0.012 \\
$X_{7}$ & 6 & 0.156 & 0.579 & 0.563 & 0.012 & 0.599 & 35.750 & 0.022 \\
\hline
\end{tabular}

Note. $\mathrm{n}=217 * p<0.05 \quad$ Source. Field Survey Data, 2014.

The equation for the multiple linear regression model for Internet competency for extension delivery is provided as:

$$
\begin{aligned}
& \mathrm{Y}=2.787+.344 X_{11}+.208 X_{10}+-.157 X_{4}+.166 X_{9}+-.184 X_{6}+.156 X_{7}+E \\
& \mathrm{Y}=2.787 \text { if } \beta_{11}=\beta_{10}=\beta_{4}=\beta_{9}=\beta_{6}=\beta_{7}=0 .
\end{aligned}
$$

Where;

Dependent Variable $(\mathrm{Y})=$ Internet Competency

$$
\begin{array}{ll}
a=\text { constant } & X_{4}=\text { Location } \\
E=\text { error term } & X_{9}=\text { Duration of use } \\
X_{11}=\text { Years of Internet use } & X_{6}=\text { Age } \\
X_{10}=\text { Training } & X_{7}=\text { Educational level }
\end{array}
$$

\section{Conclusion}

In conclusion, the results of this study provide some fascinating insights into Internet competencies of AEAs in Eastern Region of Ghana. The AEAs in Eastern Region are mostly males with low level of education and 
mainly work at the rural area. The AEAs have worked for many years but receive low salaries, and use Internet on mobile phones few hours in a week for the past five years. AEAs should be encouraged by MoFA to use other means such as social media to communicate with farmers and researchers and for downloading agricultural journals, as a way of ensuring access to Internet for extension delivery, because the AEAs currently use Internet by sending and receiving e-mails, checking pay slips and read news on agriculture.

There was significant relationship between Internet competency of AEAs and the ten independent variables of the study. Specifically the more training AEAs received on Internet use and the higher their level of education, the higher the competency level. Further, the longer time AEAs use the Internet the more competent they become. However, the more experienced AEAs have the lower level of Internet competency. AEAs with higher income have lower Internet competency. The number of years of using Internet, training, duration of Internet use, age, location and education level mainly influence the Internet competency level of AEAs. Since education level influence AEAs Internet competencies, training workshop by MoFA to improve AEAs Internet competencies should focus more on AEAs with low levels of educations, those working in rural areas, those with less frequent use of Internet and those with less number of years in the use of Internet. This will upgrade their knowledge and skills to enable them function well like their other colleagues.

Finally it is concluded that MoFA in Eastern Region can no longer play down on the need to make internet available for AEAs to carry out extension delivery duties without stress which in effect will boost agricultural production and rural life.

\section{References}

Abankwah, P. (2004). Perceived competency levels and training needs of agricultural extension agents in communication methods and teaching aids in the Greater Accra Region of Ghana (Unpublished master's thesis). University of Cape Coast, Cape Coast, Ghana.

Adesope, O. M., Asiabaka, C. C., \& Agumagu, A. C. (2007). Effect of personal characteristics of extension managers and supervisors on information technology needs in the Niger Delta area of Nigeria. International Journal of Education and Development using Information and Communication Technology, 3(2), 4-15.

Agwu, A. E., \& Chah, J. M. (2007). Access and utilization of modern information communication technologies among extension personnel in Benue State of Nigeria. In: M. C. Madukwe (Ed.), Agricultural extension and the challenges of the millennium development goals. Proceedings of the 12th Annual Conference of the Agricultural Extension Society of Nigeria (AESON) (pp. 7-21).

Agwu, A. E., Uche-Mba, U. C., \& Akinnagbe, O. M. (2008). Use of information communication technologies (ICTs) among researchers, extension workers and farmers in Abia and Enugu States: Implications for a national agricultural extension policy on ICTs. Journal of Agricultural Extension, 12(1), 37-49.

Ahmadpour, A., \& Soltani, S. (2012). Agricultural extension workers' attitude to and experience of e-learning. African Journal of Agricultural Research, 7(24), 3534-3540. https://doi.org/10.5897/ajar11.1992

Al-Hammadany, F. H., \& Heshmati, A. (2011). Determinants of Internet use in Iraq. International Journal of Communication, 5(23), 1967-1989.

Anandarajan, M., Simmers, C., \& Igbaria, M. (2000). An exploratory investigation of the antecedents and impact of internet usage: An individual perspective. Behavior \& Information Technology, 19(1), 69-85. https://doi.org/10.1080/014492900118803

Annor-Frempong, F., Kwarteng, J., Agunga, R., \& Zinnah, M. M. (2006). Challenges and prospects of infusing information communication technologies (ICTs) in extension for agricultural and rural development in Ghana. In $22^{\text {nd }}$ Annual Conference Proceedings of the Association for International Agricultural and Extension Education (AIAEE) (pp, 36-46). Clearwater Beach, Florida.

Arokoyo, T. (2005). ICTs application in agricultural extension service delivery. In F. S. Adedoyin (Ed.), Agricultural extension in Nigeria (pp. 245-251). Ilorin, Nigeria: Annual Conference of the Agricultural Extension Society of Nigeria (AESON). 
Determinants of agricultural extension agents' internet competencies in Eastern Region of Ghana

Asiedu-Darko, E. (2013). Agricultural extension delivery in Ghana: A case study of factors affecting it in Ashanti, Eastern and Northern regions of Ghana. Journal of Agricultural Extension and Rural development, 5(2), 37-41.

Bimber, B. (2000). The gender gap on the internet. Social Science Quarterly, 81(3), 868-876.

Bosompem, M., Annor-Frempong, F., \& Achiaa, Y. (2013). Perceived entrepreneurial competencies of undergraduates and self-employment creation after graduation: Implications for youth policy in Ghana. International Journal of Business and Management Studies, 2(3), 355-365.

Champoux, J. (2011). Organizational behavior: Integrating individuals, groups, and organizations (4th ed.). New York, NY: Routledge.

Cohen, J., Cohen, P., West, S. G., \& Aiken, L. S. (2003). Applied multiple regression/correlation analysis for the behavioral sciences. London, England: Lawrence Erlbaum Associates.

Crenshaw, E. M., \& Robison, K. K. (2006). Globalization and the digital divide: The roles of structural conduciveness and global connection in Internet diffusion. Social Science Quarterly, 87(1), 190-207. https://doi.org/10.1111/j.0038-4941.2006.00376.x

Davis, J. A. (1971). Elementary survey analysis. Englewood Cliffs, NJ: Prentice-Hall.

Driskill, G., \& Brenton, A. (2005). Organizational culture in action: A cultural analysis handbook. Thousand Oaks, CA: Sage Publications.

Dupuis, D. J., \& Victoria-Feser, M. (2013). Robust VIF regression with application to variable selection in large data sets. The Annals of Applied Statistics, 7(1), 319-341. https://doi.org/10.1214/12-AOAS584

Eden, M. B., \& Ofre, E. T. (2010). Reading and internet use activities of undergraduate students of the University of Calabar, Calabar, Nigeria. African Journal of Library, Archives \& Information Science, 20(1), $11-18$.

Feder, G., Just, R. E., \& Zilberman, D. (1985). Adoption of agricultural innovations in developing-countries: A survey. Economic Development and Cultural Change, 33(2), 255-298. https://doi.org/10.1086/451461

Feed the Future. (2013). Ghana. Retrieved from http://www.feedthefuture.gov/country/ghana

Fiedler, F. E. (2007). Theory of leadership effectiveness. New York, NY: McGraw-Hill.

Goulding, A., \& Spacey, R. (2002). Women and the information society: Barriers and participation. Paper presented at 68th IFLA Council and general conference, Glasgow. Retrieved from http://ericit.org/fulltext/IR058567.pdf

Hargittai E. (2008). The digital reproduction of inequality. In D. Grusky (Ed), Social stratification. Boulder (pp. 936-944). Boulder, CO: Westview Press.

Hargittai, E., \& Shafer, S. (2006). Differences in actual and perceived online skills: The role of gender. Social Science Quarterly, 87(2), 432-448. https://doi.org/10.1111/j.1540-6237.2006.00389.x

Hefny, M. A. M. (2013). Diffusion and adoption of e-extension technology (computers and the internet) among extension agents in extension work in Sohag Governorate, Egypt. African Journal of Agricultural Education, 1(5), 94-99.

Jaaskelainen, P., \& Savolaine, R. (2003). Competency in network use as a resource for citizenship implications of the digital divide. Information Research, 8(3), 153-159.

Judge, T. A., Jackson, C. L., Shaw, J. C., Scott, B. A., \& Rich, B. L. (2007). Self-efficacy and work-related performance: The integral role of individual differences. Journal of Applied Psychology, 92(1), 107-127. https://doi.org/10.1037/0021-9010.92.1.107

Knepper, E. T. (2002). Factors affecting the use of fertilizer by small-and medium-sized farming households in Zambia, 1997 to 2000 (Unpublished master's thesis). Michigan State University, Michigan.

Krejcie, R. V., \& Morgan, D. W. (1970). Determining sample size for research activities. Educational and Psychological Measurement, 30, 607-610. https://doi.org/10.1177/001316447003000308

Mabe, L. K., \& Oladele, O. I. (2012). Awareness level of use of information communication technologies tools among extension officers in the North-West Province, South Africa. Life Science Journal, 9(3), 57-62.

Marquire, J. C., Jourdan-Boddaert, L., \& Huet, N. (2002). Do older adults underestimate their actual computer knowledge? Behavior and Information Technology, 21(4), 273-280.

https://doi.org/10.1080/0144929021000020998 
Akpotosu, B. W., Annor-Frempong, F., \& Bosompem, M.

McCall, M. W. (2004). Leadership development through experience. The Academy of Management Executive, 18(3), 127-130. https://doi.org/10.5465/AME.2004.14776183

McDaniel, M. A., Anderson, J. L., \& Wildman, M. K. (2007). Using quizzes to enhance summative assessment performance in a web-based class: An experimental study. European Journal of Cognitive Psychology, 19, 494-513. https://doi.org/10.1080/09541440701326154

McDonald, T., \& Siegall, M. (2008). The effects of technological self-efficacy and job focus on job performance, attitudes, and withdrawal behaviors. Journal of Psychology, 126, 465-475. https://doi.org/10.1080/00223980.1992.10543380

Ministry of Food and Agriculture (2010). Agriculture in Ghana: Facts and figures. Accra, Ghana: Government of Ghana Publications.

Ministry of Food and Agriculture (2013). Technology Dissemination by Directorate of Agricultural Extension Services (DAES). Retrieved from http://mofa.gov.gh/site/?page_id=5267

Muijs, D. (2004). Doing quantitative research in education with SPSS. London, England: SAGE Publications Ltd. https://doi.org/10.4135/9781849209014

Mukoko, B. (2012). Determinants of computer and internet adoption and use in Cameroon. African Review of Economics and Finance, 3(2), 96-128.

O’Brien, R. M. (2007). A caution regarding rules of thumb for variance inflation factors. Quality \& Quantity. 41, 673-690. https://doi.org/10.1007/s11135-006-9018-6

Ogunjobi, T. E., \& Fagbami, O. O. (2012). Use of internet by researchers in agricultural research institutes in Ibadan, Oyo state. International Journal of Library and Information Science, 4(4), 52-56. https://doi.org/10.5897/IJLIS11.068

Ojedokun, A. O., \& Owolabi, E. O. (2003). Internet access competence and the use of the internet for teaching and research activities by University of Bostwana academic staff. African Journal of Library, Archives and Information Science, 13(1) 43-53.

Okay, S. (2010). A research on investigation of Internet using purposes of technical teacher candidates. Electronic Journal of Machine Technologies, 7, 97-109.

Oketunji, I. (2001). Libraries and the Internet connectivity: What benefits? In J. Lasis, O. K. Odunsanya, S. E. A. Sonaike, \& L. F. Osinulu (Eds.), Automation of cataloguing practices in Nigerian libraries (pp.32-40). Ijebu-Ode, Nigeria: Nigerian Library Association.

Oladele, O. I. (2010). Information sources use patterns among agricultural researchers in Southwestern Nigeria. The Journal of International Social Research, 3(12), 322-326.

Ono, H., \& Zavodny, M. (2003). Gender and the internet. Social Science Quarterly, 84(1), 111-121. https://doi.org/10.1111/1540-6237.t01-1-8401007

Osei-Boateng, A. (2012, September 9). Ghana to adopt e-extension service to boost agriculture productivity. China.org.cn. Retrieved from http://www.china.org.cn/world/Off_209/19/content.htm

Rohde, G. L., \& Shapiro, R. (2000). Falling through the net: Toward digital inclusion. A report on Americans' access to technology Tools. New York, NY: Guilford Press.

Ruzgar, N. S. (2005). A research on the purpose of Internet usage and learning via Internet. The Turkish Online Journal of Educational Technology, 4(4), 27-32.

Scheer, S. D. (2011). Competency modeling in extension education: integrating an academic extension education model with an extension human resource management model. Journal of Agricultural Education, 52(3), 64-74. https://doi.org/10.5032/jae.2011.03064

Schumacher, P., \& Morahan-Martin, J. (2001). Gender, internet and computer attitudes and experiences. Computers in Human Behavior, 17(1), 95-110. https://doi.org/10.1016/S0747-5632(00)00032-7

Sinkaye, T. (2005). Agricultural extension participatory methodologies and approaches. In S. F. Afolayan (Ed.), Agricultural Extension in Nigeria (pp. 220-233). Ilorin, Nigeria: Annual Conference of the Agricultural Extension Society of Nigeria (AESON).

Stanovich, K. (2007). How to think straight about psychology. Boston, MA: Pearson.

Steers, R. (2011). Introduction to organizational behavior. Glenview, IL: Scott-Foresman.

Taylor, W. J., Zhu, G. X., Dekkers, J., \& Marshall, S. (2012). Socio-economic factors affecting home internet 
usage patterns in Central Queensland. Informing Science Journal, 6(1), 233-242.

Teo, T. S. H. (2001). Demographic and motivation variables associated with Internet usage activities. Internet Research: Electronic Networking Applications and Policy, 11(2), 125-137. https://doi.org/10.1108/10662240110695089

Vanderstoep, S. W., \& Johnston, D. D. (2009). Research methods for everyday life: Blending qualitative and quantitative approaches. San Francisco, CA: Jossey-Bass.

van Deursen, A. J. A. M. (2010). Internet skills. Vital assets in an information society. Enschede, the Netherlands: University of Twente.

Wasserman, I. M., \& Richmond-Abbott, M. (2005). Gender and the internet: Causes of variation in access, level, and scope of use. Social Science Quarterly, 86(1), 252-270. https://doi.org/10.1111/j.0038-4941.2005.00301.x

Wunnava, P. V., \& Leiter, D. B. (2009). Determinants of intercountry internet diffusion rates. American Journal of Economics and Sociology, 68(2), 413-426. https://doi.org/10.1111/j.1536-7150.2009.00634.x

Xiaoming, H., \& Kay, C. S. (2004). Factors affecting Internet development: An Asian survey. First Monday, 9(2), 1-21. https://doi.org/10.5210/fm.v9i2.1118

Yakubu, D. H. (2011). Socio-economic factors affecting the adoption of ICTs by extension workers in the North-West zone of Nigeria (Unpublished Master's thesis). Usmanu Danfodiyo University, Sokoto, Nigeria.

Zhang, Y. (2004). Age, gender, and internet attitudes among employees in the business world. Computers in Human Behavior, 21, 1-10. https://doi.org/10.1016/j.chb.2004.02.006

Zwane, E. M. (2009). Participatory development of an extension approach and policy for Limpopo province South Africa (Unpublished Doctoral thesis). University of Pretoria, Pretoria, South Africa. 
Akpotosu, B. W., Annor-Frempong, F., \& Bosompem, M. 